\title{
BACTERIOCIN ACTIVITY OF STAPHYLOCOCCUS AUREUS, STAPHYLOCOCCUS INTERMEDIUS AND COAGULASE-NEGATIVE STAPHYLOCOCCAL STRAINS
}

\author{
B. SKALKA \\ Department of Epizootiology and Microbiology, University of Veterinary Science, 61242 Brno
}

Received September 5, 1984

\begin{abstract}
Skalka B.: Bacteriocin Activity of Staphylococcus aureus, Staphylococcus intermedius and Coagulase-negative Staphylococcal Strains. Acta vet. Brno, 55, 1986: $65-72$.

A total of 567 staphylococcal strains was examined for bacteriocin activity. It contained $367 S$. aureus strains, $114 S$. intermedius strains, and 86 coagulasenegative staphylococci belonging to ten species. The deferred method was employed for detecting bacteriocin producers. Bacterial strains $C$. renale, $C$. pseudodiphtheriticum, S. aureus CB-27 and S. aureus Oxford 209P served as indicators. A total of 82 bacteriocin producers was determirfed among the strains under study, 12 of them belonging to $S$. aureus, 51 to $S$. intermedius, and 19 to the coagulase-negative staphylococci. According to their effects on indicator strains, the bacteriocin producing staphylococci were alloted into 12 groups. The method employed is recommendable for detection of the ability of staphylococcal strains to produce bacteriocins.
\end{abstract}

Staphylococcal bacteriocins, $S$. aureus, $S$. intermedius, coagulase-negative staphylococci, deferred method.

Since the last century, bacteriology has been familiar with the antibacterial activity of some staphylococci consisting essentially in production of an exosubstance, referred to as bacteriocin or staphylococcin. Alike analogous exosubstances from other Gram-positive bacteria, staphylococcal bacteriocins show discrepancies from classical criteria originally based on the characteristics of colicins (Tagg et al. 1976; Brandis 1981).

To be considered as bacteriocin, an antagonistic active exosubstance is supposed to act merely within one species or a group of closely related ones. This criterion is mostly not answered by bacteriocins of Gram-positive bacteria, displaying as a rule a wide spectrum of activity. Bacteriocin production has to be plasmid-borne. The action exerted on sensitive bacteria is bactericidal preserving the morphologic integrity of cells. This is achieved by inhibiting synthesis of nucleic acids and/or cell proteins. The criteria were analyzed and reviewed in detail by Tagg et al. (1976), Pulverer and Jeljaszewicz (1976), Brandis (1981), Ivanov (1983). In case an antagonistic bacterial substance fails to be determined in details, or the criteria have not been fulfilled, it was recommended by the authors quoted to refer to it as to a bacteriocin-like substance.

Studies on staphylococcins were stimulated by the observation that by exfoliatin-positive $S$. aureus strains the production of both exfoliative toxin and staphylococcin BacR 1 was encoded on the same plasmid (Parker et al. 1955; Parker and Simmons 1959; Rogolsky et al. 1974; Warren et al. 1974).

Most work has been done on staphylococcins A-1262a (Lachowicz 1965), C 55 (Dajani et al. 1970), 414 (Gagliano and Hinsdill 1970) and 1580 (Jetten and Vogels 1972). The designations micrococcin, aureocin, and epidermidin, were used for some antagonistic substances of staphylococci by some authors (Heatley and Doery 1951; Moore 1970; Hsu and Wise man 1971).

To detect production of staphylococcin, either the simultaneous or the deferred methods are employed. Using the first method, active and indicator strains are cultured at the same time, 
in the deferred method the test organism is cultured in advance and the susceptible indicator strain is added after a period of time. Both methods were used and compared in our previous studies (Skalka et al. $1983 \mathrm{a}, \mathrm{b}$ ).

Determining staphylococcin producing strains depends upon the susceptibility of the indicator strain (Parker and Simmons 1959). Pulverer and Sieg (1972) found that merely twelve out of $300 S$. aureus strains were convenient indicators. The importance of the indicators was also emphasized by many authors (Tagg et al. 1976; Šmarda and Obdržálek 1981; Brandis 1981; Ivanov 1983), and it was discussed in our earlier papers (Skalka et al. $1983 \mathrm{a}, \mathrm{b}$ ).

Authors studying staphylococcins did not, and were not in a position to, take into account the recent classification of the genus Staphylococcus, and they used mostly $\boldsymbol{S}$. aureus strains as indicators. When detecting bacteriocin producing staphylococcal strains, we considered not only the actual taxonomy, but we also employed larger number of species as indicators.

\section{Materials and Methods}

\section{Media}

Nutrient broth No. 1 and Blood agar base No. 4 (both Immuna). Nutrient broth CM2 and Nutrient agar CM3 (both Oxoid ltd.) were used. All media were adjusted to pH 7.4.

\section{Bacterial strains}

$S$. aureus strain UT0002 producing the staphylococcin BacR 1 served for checking.

The strains Corynebacterium renale, CCM 5740, Corynebacterium pseudodiphtheriticum, CNCTC Psdi 5/78, S. aureus Oxford 209P CNCTC Mau 28/58, and $S$. aureus, CB-27 were employed as indicators.

Staphylococcal strains isolated from man, poultry, dog, and bovine udders were used for screening antagonistic activities, and were represented by $367 \mathrm{~S}$. aureus strains including 62 biovar A, 23 biovar B, 192 biovar C1, 85 biovar C2, and 5 biovar D, further by $114 S$. intermedius strains and 86 coagulase-negative staphylococci including $23 S$. haemolyticus, $20 S$. epidermidis, 16 S. hominis, 8 S. xylosus, 5 S. capitis, 5 S. hyicus, 4 S. simulans, $2 S$. saprophyticus, $2 S$. cohnii and $1 S$. caprae strains.

\section{Detection of staphylococcins}

The production of staphylococcins was detected using the deferred method for the test strains as described previously (Skalka et al. $1983 \mathrm{~b}$ ). The strains under study were cultured in the form of spots on the surface of agar medium and incubated at $37^{\circ} \mathrm{C}$ for $48 \mathrm{~h}$. Then a suspension of indicator strain was sprayed on the agar. The results were read after another $24 \mathrm{~h}$ of incubation

Table 1

Bacteriocin activity of the investigated staphylococcal strains

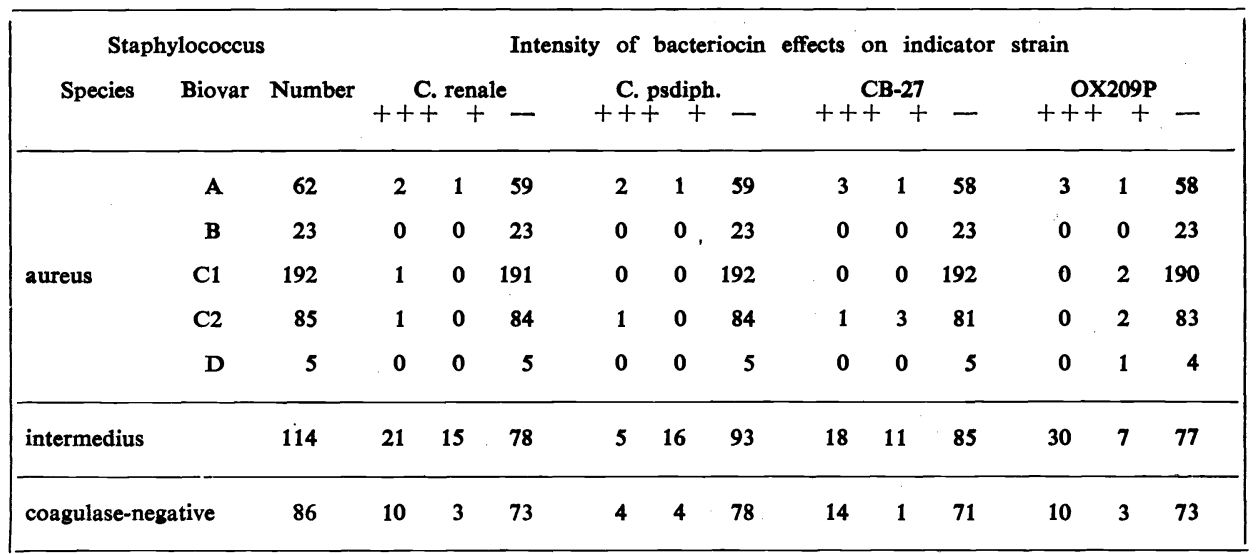

Legends:

Bacteriocin effect: $+++=$ intensively positive, $+=$ positive, $-=$ negative

C. psdiph. $=$ C. pseudodiphtheriticum, CB-27 $=$ S. aureus CB-27, OX209P $=$ S. aureus Oxford 209P 
at $37^{\circ} \mathrm{C}$. The zone of growth inhibition of indicator strain was evaluated as intensively positive $(+++)$ when the width of its ring exceeded $5 \mathrm{~mm}$. A smaller zone was noted as positive $(+)$, and the absence of inhibition was considered a negative result $(-)$.

\section{Results}

Among 567 staphylococcal strains tested, 82 exerted antagonistic activity on at least one from four indicator strains. The least active of all were $S$. aureus strains with only $12(3.26 \%)$ strains causing inhibitory effects. From coagulase-negative strains, nineteen $(22.09 \%)$ were bacteriocin producers. The largest number of active strains was detected within the species $S$. intermedius corresponding to $51(44.73 \%)$ producers.

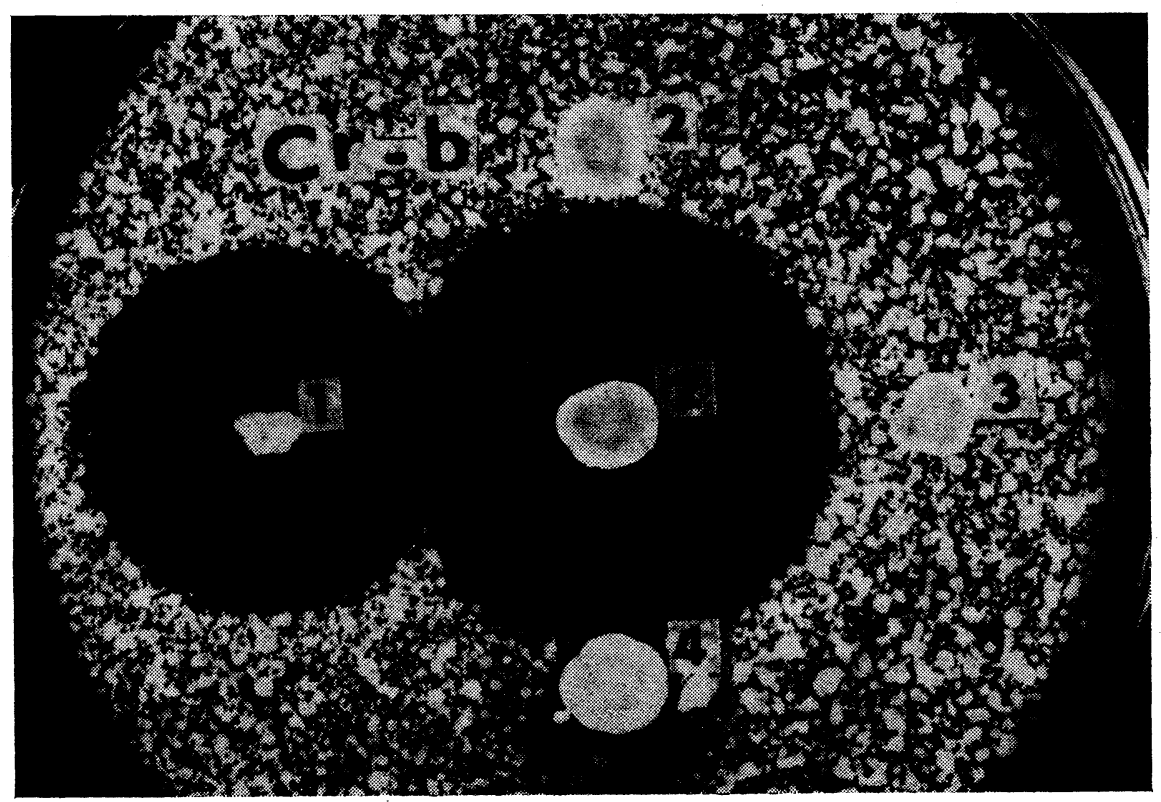

Fig. 1

Bacteriocin activity of the strains S. intermedius OP-25 (1), S. aureus UT0002 (2), S. aureus UT0002* Back 1 (2*), S. intermedius OP-11 (3), S. epidermidis Dg250 (4) on the indicator strain C. renale (Cr-b).

Only four active strains were detected among 62 S. aureus members of biovar A, two of them proceeding from humans, one from a horse and one from bovine udder. No producer was detected among 23 strains of biovar B. Merely three producers were established among 192 strains of biovar $\mathrm{Cl}$, two of them originated from bovine udders and one from a dog. Among 85 strains of biovar C2, four produced antagonistic effects, and they were isolated from atypical hosts, namely two from humans and two from dogs. One strain was active from five belonging to biovar D, and it inhibited only the indicator strain S. aureus Oxford 209P.

Among coagulase-negative staphylococci, $S$. hominis provided five producers, our were detected among $S$. epidermidis strains, three among $S$. xylosus two pro- 


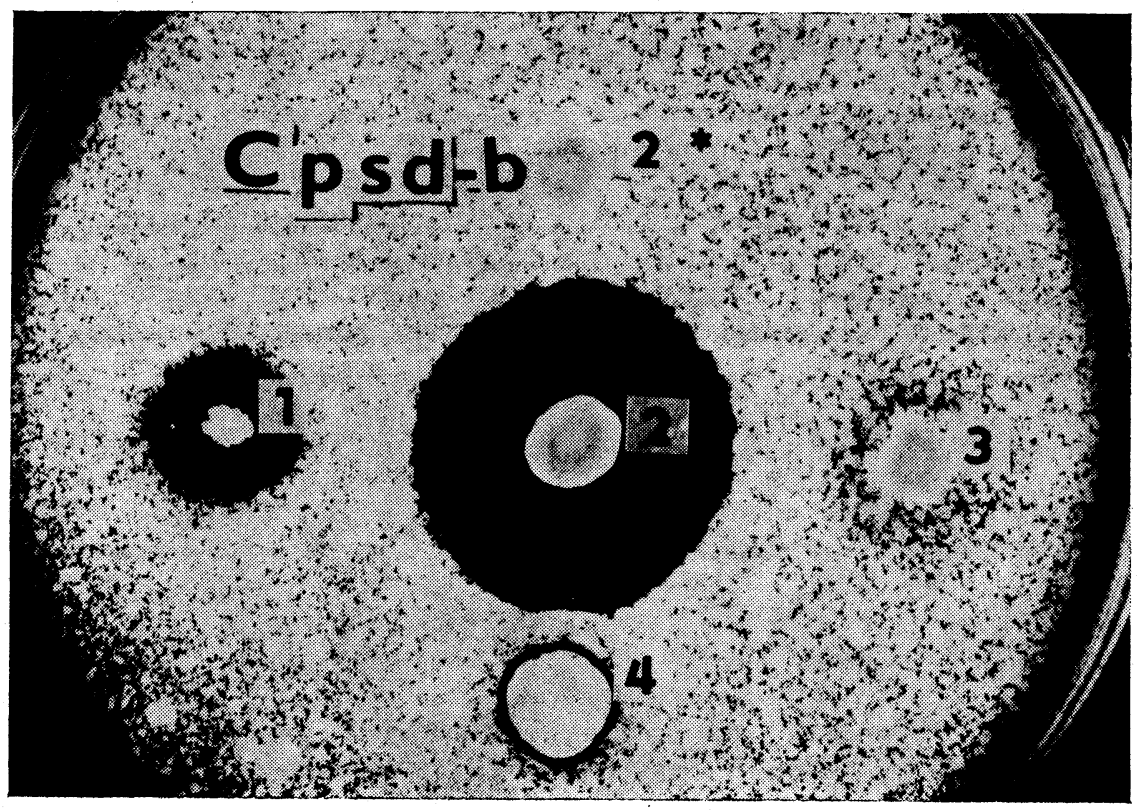

Fig. 2

Bacteriocin activity of the same strains as on Fig. 1 using C. pseudodiphtheriticum (C. psd-b) as indicator.

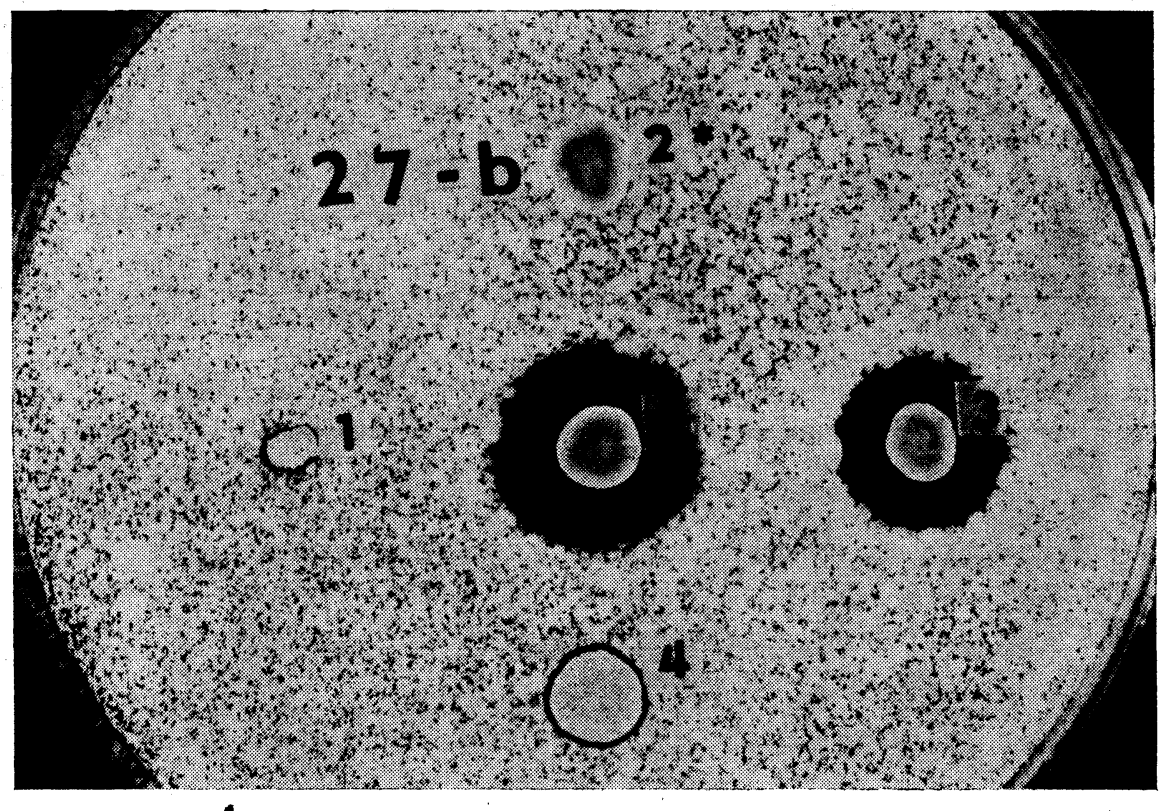

Fig. 3

Bacteriocin activity of the same strains as on previous figures tested on S. aureus CB-27 (27-b). 
ducers among $S$. saprophyticus and among $S$. haemolyticus and among $S$. hyicus, $S$. capitis, $S$. caprae one producer each.

From 82 active staphylococci, 54 strains acted on $C$. renale, 35 of them in an intensively positive, 19 in a positive way. C. pseudodiphtheriticum was affected by 33 strains, by 12 of them to an intensively positive, and by 21 to a positive degree, 52 producers were bactericidal for $S$. aureus CB-27, 36 of them exerting an intensively positive and 16 a positive effect. The indicator strain $S$. aureus Oxford 209P was affected by 59 producers, by 43 of them to an intensively positive and by 16 to a positive degree (Table 1; Figs. 1-4).

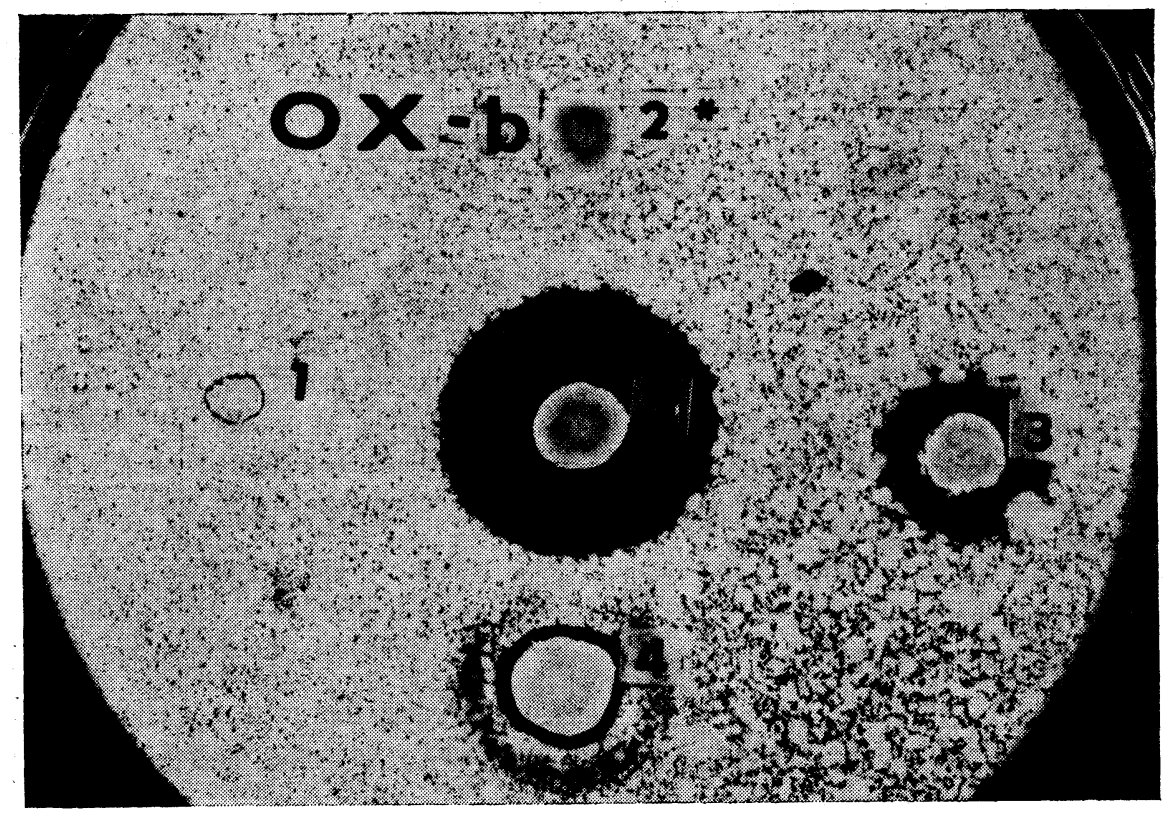

Fig. 4

Bacteriocin activity of the same strains as on previous figures tested on the indicator strain S. aureus Oxford 209P (OX-b).

Bacteriocin substances produced by active staphylococcal strains had not an equal effect on the indicators employed by us. With regard to their activity patterns, they could be distributed into twelve groups (Table 2).

\section{Discussion}

Alike many topics concerning staphylococci, no uniform technique for estimation of staphylococcins has been accepted up to the present. This accounts for the variety of results reported.

There is partial agreement for the importance of indicator strains, nevertheless even in this field recommendations vary from employing one (Lachowicz 1965; Warren et al. 1974) or two essential strains (Iva nov 1983), up to the recommendation to test all strains under study both as producers and indicators (Pulverer and Sieg 1972; Šmarda and Obdržálek 1981). We are convinced that no a large 
Table 2

Activity patterns of baetoriocin producing strains

\begin{tabular}{|c|c|c|c|c|c|c|}
\hline \multicolumn{3}{|c|}{ Sensitivity of indicator strains } & & \multicolumn{3}{|c|}{ Number of active strains of Staphylococcus } \\
\hline C. $r$. & & & Ox & & intermedius & coagulase-negative \\
\hline+ & + & + & + & 3 & 12 & 6 \\
\hline - & - & + & + & 1 & 7 & 5 \\
\hline+ & - & - & - & 1 & 6 & 2 \\
\hline+ & - & + & + & 1 & 6 & 2 \\
\hline - & - & - & + & 3 & 3 & $\mathbf{0}$ \\
\hline - & - & + & - & 2 & 4 & $\mathbf{0}$ \\
\hline+ & + & - & + & $\mathbf{0}$ & 5 & $\mathbf{0}$ \\
\hline+ & + & - & - & $\mathbf{0}$ & 3 & 1 \\
\hline+ & - & - & + & $\mathbf{0}$ & 4 & $\mathbf{0}$ \\
\hline+ & 一 & + & - & 0 & o & 2 \\
\hline - & + & - & - & $\mathbf{0}$ & 1 & 1 \\
\hline- & + & + & + & 1 & 0 & 0 \\
\hline
\end{tabular}

Legends:CB27 $=$ S. aureus CB-27 OX $=$ S. aureus Oxford 209P

: C. r. $=$ C. renale C. psd $=$ C. pseudodiphtheriticum

$:=$ growth inhibition of the indicator strain

$-=$ normal growth of the indicator strain

number of indicators should be used when routine detection of staphylococcm production is intended as diagnostical feature. With regard to the characteristics of staphylococcins (Parker et al. 1955; Parker and Simmons 1959; Pulverer and Jeljaszewicz 1976; Tagg et al. 1976; Brandis 1981) and our experience (Skalka et al. $1983 \mathrm{a}, \mathrm{b}$ ), we chose four bacterial strains as indicators, two of them of the species $S$. aureus and two susceptible Corynebacterium spp. we have used and recommended earlier.

The high detection rate due to the deferred method was the reason why many authors recommended this technique (Parker and Simmons 1959; Gagliano and Hinsdill 1970; Jetten and Vogels 1972), and why we made use of it in the present study.

It is hardly possible to compare our results with reported data, the more so since no differentiating has been made between both coagulase-positive staphylococcal species. The present study implied that such a differentiation was substantial and necessary considering the different incidence of bacteriocin production in $S$. aureus and $S$. intermedius strains.

The percentage of bacteriocin producing coagulase-negative staphylococci we detected is in agreement with most data reported. Though we related our findings to the species of coagulase-negative strains, we attribute them not more than a value of orientation, since the number of this staphylococci employed in this study was small and unevenly distributed.

The present level of information about staphylococcal bacteriocins is sufficient to make them available for diagnostical purposes. Further studies carried out by standard techniques will doubtlesly lead to ecological conclusions which would be reflected in epizootiology and epidemiology of staphylococci.

\section{Bakteriocinová aktivita kmenů Sptahylococcus aureus, Staphylococcus intermedius a koaguláza-negativních stafylokoků}

Byla zjištována bakteriocinová aktivita u 567 stafylokokových kmenů, ze kterých 367 náleželo ke druhu Staphylococcus aureus, 114 ke druhu Staphylococcus intermedius a 86 bylo koaguláza-negativních, řadících se do 10 druhů. Byla použita metoda předkultivace testovaných kmenů. Jako indikátory byly použity kmeny Coryne- 
bacterium renale, Corynebacterium pseudodiphtheriticum, S. aureus CB-27 a $S$. aureus Oxford 209P. Bylo urceno celkem 82 bakteriocin produkujících kmenů, $\mathrm{z}$ toho 12 kmenů náleželo k $S$. aureus, $51 \mathrm{k}$ S. intermedius a 19 bylo koaguláza-negativních stafylokokủ. Na podkladě spektra účinku na indikátorové kmeny vytvơ̌ily bakteriocin-pozitivní stafylokoky 12 rozdílných skupin. Použitá metoda je doporučena.jako základ pro standardizaci detekce stafylokokových bakteriocinů.

\section{Бактериоциновая активность штаммов Staphylococcus aureus, Staphylococcus intermedius и коагулаза-отрицательных стафилококков}

Проводились исследования бактериоциновой активности 567 стафилококковых штаммов, из них 367 принадлежало к виду Staphylococcus aureus, 114 - к виду Staphylococcus intermedius и 86 было коагулазаотрицательных, входящих в 10 видов. Был использован метод предварительной культивации проверяемых штаммов. В качестве индикаторов были использованы штаммы Corynebacterium renale, Corynebacterium pseudodiphtheriticum, S. aureus CВ-27 и S. aureus Oxford 209P. В итоге было определено 82 штамма, продуцирующих бактериоцин, из этого 12 штаммов принадлежали к $S$. aureus, 51 штамм - к $S$. intermedius и 19 - коагулаза-отрицательные стафилококки. На основе спектра воздействия на индикаторные штаммы бактериоцин-положительные стафилококки образовали 12 разныг групп. Используемый метод рекомендован в качестве основы стандартизации определения стафилококковых бактериоцинов.

\section{References}

BRANDIS, H.: Bacteriocins with special consideration to staphylococcins. Zbl. Bakt. Hyg. I. Abt., Suppl. 10, 1981: 719-729.

DAJANI, A. S. - GRAY, E. D. - WANNAMAKER, L. W.: Bactericidal substance from Staphylococcus aureus: Biological properties, J. Exp. Med., 131, 1970: 1 004-1 015.

GAGLIANO, V. J. - HINSDILL, R. D.: Characterization of a Staphylococcus aureus bacteriocin. J. Bacteriol., 104, 1970: 117-125.

HEATLEY, N. G. - DOERY, H. M.: The preparation and some properties of purified micrococcin. Biochem. J., 50, 1951: 247-253.

HSU, C. Y. - WISEMAN, G. M.: Purification of epidermidins, new antibiotics of staphylococci. Canad. J. Microbiol., 17, 1971: $1223-1226$.

IVANOV, N. A.: Baktěriocinogenija stafilokokov. Žurnal Mikrobiol. Epidemiol. Immunol., No. 9, 1983: 3-7.

JETTEN, A. M. - VOGELS, G. D.: Nature and properties of a Staphylococcus epidermidis bacteriocin. J. Bacteriol., 112, 1972: 243-250.

LACHOWICZ, T.: Investigations on staphylococcins. Zbl. Bakt. Hyg. I. Abt. Orig. 196, 1965: $340-351$.

MOORE, E. E. M.: Aureocin. J. Med. Microbiol., 3, 1970: 183-184.

PARKER, M. T. - SIMMONS, L. E.: The inhibition of Corynebacterium diphtheriae and other Gram-positive organisms by Staphylococcus aureus. J. Gen. Microbiol., 21, 1959: 457-476.

PARKER, M. T. - TOMLINSON, A. J. H. - WILLIAMS, R. E. O.: Impetigo contagiosa. The association of certain types of Staphylococcus aureus and of Streptococcus pyogenes with superficial skin infections. J. Hyg. (Camb.), 53, 1955: 458-473.

PULVERER, G. - JELJASZEWICZ, J.: Staphylococcal micrococcins. Zbl. Bakt. Hyg. I. Abt., Suppl. 5, 1976: 599-621.

PULVERER, G. - SIEG, J. F.: Bakteriocinotypie bei Staphylococcus aureus. Zbl. Bakt. Hyg., I. Abt. Orig. A 222, 1972: 466-458.

ROGOLSKY, M. - WARREN, R. - WILEY, B. B. - NAKAMURA, H. T. - GLASGOW, L. A.: Nature of the genetic determinant controlling exfoliative toxin production in Staphylococcus aureus. J. Bacteriol., 117, 1974: 157-165. 
SKALK.A, B.: Výzkum ekologie a zkřižené patogenity kmenů Staphylococcus aureus z různých hostitelů. Project report, 1984, Brno, 44 s.

SKALKA, B. - PILLICH, J. - POSPÍSIL, L.: New possibilities of staphylococcin detection in the exfoliatin-producing strains of Staphylococcus aureus. Zbl. Bakt. Hyg., I. Abt. Orig. A 254, 1983a: 34-41.

SKALKA, B. - PILLICH, J. - POSPÍSIL, L.: Further observations of Corynebacterium renale as an indicator organism in the detection of the exfoliatin-positive strains of Staphylococcus aureus. Zbl. Bakt. Hyg. A 256, 1983b: 168-174.

ŠMARDA, J. - OBDRŽÁLEK, V.: Staphylococcins: Incidence and some characteristics of antibiotic action. Zbl. Bakt. Hyg. I. Abt. Suppl. 10, 1981: 407-411.

TAGG, J. R. - DAJANI, A. S. - WANNAMAKER, L. W.: Bacteriocins of gram-positive bacteria. Bacteriol. Rev., 40, 1976: 722-756.

WARREN, R. - ROGOLSKY, M. - WILEY, B. B. - GLASGOW, L. A.: Effect of ethidium bromide on elimination of exfoliative toxin and bacteriocin production in Staphylococcus aureus. J. Bacteriol., 118, 1974: 980-985. 